\title{
Supra-company apprenticeship training in Austria: a synopsis of empirical findings on a possibly early phase of a new pillar within VET
}

\author{
Peter Schlögl $\left.\right|^{1 *} \mathbb{D}$, Martin Mayerl ${ }^{2}$, Roland Löffler ${ }^{2}$ and Alexander Schmölz²
}

${ }^{*}$ Correspondence:

peter.schloegl@aau.at

${ }^{1}$ Department of Educational Science, University

Klagenfurt, Universitätsstraße 65-67, 9020 Klagenfurt am

Wörthersee, Austria

Full list of author information is available at the end of the article

\begin{abstract}
Since 2008, the Austrian Vocational Training Act has given young people the opportunity to obtain vocational qualifications in supra-company training workshops. In addition to the traditional full-time vocational school system and company-based apprenticeship training, a third vocational qualification path has thus been established. This article presents empirical findings on this innovation in skill formation and examines the question of whether conditions for the sustainable establishment of a third pillar for acquiring vocational qualifications are given with regard to regulatory, normative, and cultural cognitive dimensions.
\end{abstract}

Keywords: Youth unemployment, Skill formation, Apprenticeship training, Path dependency, Mismatch

\section{Introduction}

For some time now, research has investigated the question of how a full-time vocational education and training (VET) in schools as well as an apprenticeship system was successfully established in Austria. The apprenticeship system (70-80\% of training takes place as in-company training and $20-30 \%$ in part-time vocational schools), continues to engage a relevant proportion of school-leavers and companies continue to display a willingness to offer (and benefit from) in-company initial vocational education and training (Graf et al. 2012). Nevertheless, the number of companies offering apprenticeships is continuously decreasing (Dornmayr and Nowak 2019, p. 38). This is an indicator that apprenticeship training has changed considerably over the last two decades. This is due, for example, to a change in demand for skilled workers (Goos et al. 2009) as a result of further expansion of the service sector and a related increase in qualification requirements, as well as a change in the educational choices of young people, leading to greater social selection and the opening up of new recruitment channels for skilled workers (Busemeyer and Trampusch 2012). 37\% of young people at upper secondary level are pursuing an apprenticeship, 39\% attend a full-time vocational school or college

(c) The Author(s) 2020. This article is licensed under a Creative Commons Attribution 4.0 International License, which permits use, sharing, adaptation, distribution and reproduction in any medium or format, as long as you give appropriate credit to the original author(s) and the source, provide a link to the Creative Commons licence, and indicate if changes were made. The images or other third party material in this article are included in the article's Creative Commons licence, unless indicated otherwise in a credit line to the material. If material is not included in the article's Creative Commons licence and your intended use is not permitted by statutory regulation or exceeds the permitted use, you will need to obtain permission directly from the copyright holder. To view a copy of this licence, visit http://creativeco mmons.org/licenses/by/4.0/. 
and 24\% attend a general secondary school (Dornmayr and Nowak 2019, p. 105, school year 2016/17).

In this context, less consideration has been given to the fact that a third, hybrid pillar has been developed since the end of the last millennium: the Supra-Company Apprenticeship Training (SCAT). SCAT is an apprenticeship scheme in which practical training is offered by supra-company training providers rather than companies themselves. Practical training is carried out as simulative learning in workshops (comparable to the workshop setting in VET schools). Depending on the form of implementation, however, extended phases of in-company placements in cooperating companies are also possible. In-company placements in SCAT have the primary goal of facilitating transition to a regular company-based apprenticeship. SCAT graduates leave with a regular apprenticeship certificate for a specific occupation profile. The training lasts between three and four years (although in some exceptional cases it lasts only two years). SCAT is an inclusive programme which, although largely based on non-company training, offers interfaces for integration with training companies through in-company placements (Bonoli and Wilson 2019). Since the introduction of SCAT, the share of young people on this programme has risen from 5.6\% (2009) to 7.7\% (2018) (Dornmayr and Nowak 2019, p. 16).

SCAT was initially intended to address an economic and demographic imbalance in the apprenticeship market caused by structural factors (Schneeberger 2009). Many apprenticeship seekers were unsuccessful, meaning that the apprenticeship market was not able to absorb demand, while VET school capacities were invariable. The Austrian government reacted to this with several different measures (Schlögl 2017). On the one hand, measures were taken to make apprenticeship training more attractive to companies and young people. Some examples are the introduction of a financial subsidy scheme to encourage firms to increase their capacity for company-based apprenticeship training. Additionally, guidance and counselling in schools was intensified and measures were also taken to make apprenticeships more attractive to high-performing school leavers (e.g. by introducing a supplementary examination for apprentices graduates to allow them to access university).

On the other hand, non-company training places (namely SCAT) were also provided, initially planned as a temporary measure. A major impetus was education- and labourmarket interest in ensuring the inclusiveness of apprenticeship systems for all interested young people.

\section{The emergence of a structural element: SCAT as a third pillar of IVET}

Against this background, the qualification model SCAT emerged as a structural element of the Austrian VET system in the second half of the 1990s (Schlögl et al. 2019). International research has shown that countries with a similar apprenticeship system have been tackling the crisis in the apprenticeship market with different measures (Lassnigg 2017; Bonoli and Wilson 2019). For example, the German transition system targeted young people in welfare schemes and social care. This shifted the problem to a prevocational measure (Protsch and Solga 2016). Switzerland has undertaken a systemic reform of the VET system, which resulted in the introduction of fast-track apprenticeships (Di Maio et al. 2020). These examples show the international relevance of quick reactions to crises 
on the part of VET systems by balancing economic efficiency and inclusiveness (Bonoli and Wilson 2019; Di Maio et al. 2019).

However, we do not pursue the path of international comparison here; rather we want to scrutinize the process of institutionalization of SCAT in the Austrian VET system. Although some research has been undertaken on SCAT, there remains a lack of critical debate about the emergence of a 'third pillar' in VET in the context of an already highly differentiated VET system.

\section{Theoretical framework}

For analysis we refer to the theoretical framework of neo-institutionalism (Powell and DiMaggio 1991; Lowndes and Roberts 2013; Scott 2014). We define our object of research, namely SCAT, as an organization field "that, in the aggregate, constitutes a recognized area of institutional life" (DiMaggio and Powell 1983, p. 148). On the one hand, an organization field is a relational concept that refers to a social space which is characterised by specific social relations between actors and organizations. On the other hand, it also refers to the fact that a social field is permanently in progress and must respond to the environment. For our analysis of SCAT we draw on the three key dimensions of legitimation: regulative, normative, and cultural-cognitive, as suggested by Scott (2014). We also refer to Di Maio et al. (2019), who use an analogous framework for their international comparison of responses to the national apprenticeship crisis.

The regulatory dimension applies to the legal development and implementation of SCAT. In this dimension we focus primarily on the governance system of collective VET systems (see e.g. Busemeyer and Trampusch 2012). Emmenegger et al. (2019, p. 11), in their analytical framework, emphasize six core task areas of cooperation in collective VET systems that should be included in any analysis: (1) the system development of SCAT: strategic and legal reforms and implementations; (2) the content definition: aims and learning outcomes of training in SCAT; (3) the organization of training provision: the concrete implementation and administration of SCAT; (4) the matching of demand and supply: the formal process of matching supply from SCAT with demand in the labour market; (5) the financing of SCAT; and (6) the monitoring and examination of training outcome in terms of quality control and development.

According to Scott (2014, p. 64) the normative dimension:

include[s] both values and norms. Values are conceptions of the preferred or the desirable together with the construction of standards to which existing structures or behaviors can be compared and assessed. Norms specify how things should be done; they define legitimate means to pursue valued ends.

In this context, we see the objectives at which SCAT aims, as introduced by education- and labour-market policy, as a relevant unit of analysis. They can be used to assess whether the normative objectives associated with SCAT are being met. A second aspect of the normative pillar relates to different standards of implementation. In general, the governance and implementation of collective VET systems is characterized by a multilevel structure with numerous decentralized actors (Emmenegger et al. 2019). This may lead to institutional variation in both implementation and standards in different regional and occupational areas. 
The cultural-cognitive dimension refers to intersubjective social meanings: "the shared conceptions that constitute the nature of social reality and create the frames through which social meaning is made" (Scott 2014, p. 67). According to Bourdieu (1987), formal vocational qualifications can be understood as symbolic capital. VET qualifications acquired through SCAT are legally equivalent to the VET qualification of a conventional, company-based apprenticeship. Nevertheless, there is the question of the symbolic recognition of SCAT certificates on the labour market. Furthermore, the active involvement of companies in making the VET system more inclusive is considered an important requirement (Bonoli and Wilson 2019). Therefore, we ask for the rationale and motivation (Schönfeld et al. 2010) as to why training companies cooperate with SCAT institutions (e.g. in offering an internship). And finally, the perspective of the central target group, namely young people (conceived in Scott's framework as actors) must also be included in the analysis. It may be assumed that the institutionalization process is also largely dependent on whether the institution can be accepted by central actors and whether institutional structures can be reproduced. In the institutional literature on VET, raising the educational aspirations of young people in the context of an academic drift is defined as a key challenge for VET governance (Busemeyer and Trampusch 2012).

\begin{tabular}{|c|c|c|c|}
\hline Dimension & Regulative dimension & Normative dimension & $\begin{array}{l}\text { Cultural-cognitive } \\
\text { dimension }\end{array}$ \\
\hline Key institution & $\begin{array}{l}\text { Laws, statutory regulations, } \\
\text { guidelines }\end{array}$ & $\begin{array}{l}\text { Standards, values and } \\
\text { norms }\end{array}$ & $\begin{array}{l}\text { Recognition, rationals, } \\
\text { acceptance }\end{array}$ \\
\hline Guiding question & $\begin{array}{l}\text { How is SCAT regulated by } \\
\text { law? What does the gov- } \\
\text { ernance structure look } \\
\text { like? Which actors are } \\
\text { involved in the coopera- } \\
\text { tive process? }\end{array}$ & $\begin{array}{l}\text { What are the values and } \\
\text { norms associated with } \\
\text { SCAT measures? Is there } \\
\text { institutional variation } \\
\text { through different stand- } \\
\text { ards of implementation? }\end{array}$ & $\begin{array}{l}\text { Is the formal equivalence of } \\
\text { certificates also sym- } \\
\text { bolically recognized on } \\
\text { the labour market? What } \\
\text { rationales and consid- } \\
\text { erations are behind the } \\
\text { involvement of companies? } \\
\text { Is the qualification model } \\
\text { accepted by the target } \\
\text { group? }\end{array}$ \\
\hline Indicators for analysis & $\begin{array}{l}\text { Historical development, } \\
\text { legal implementation, } \\
\text { actors, governance struc- } \\
\text { ture of SCAT, financing }\end{array}$ & $\begin{array}{l}\text { Normative goals of SCAT } \\
\text { Measures defined } \\
\text { by policy, standards } \\
\text { of implementation } \\
\text { (regional, occupation) }\end{array}$ & $\begin{array}{l}\text { Pathways into the labour } \\
\text { market, motives and ration- } \\
\text { ales of companies, accept- } \\
\text { ance of participants }\end{array}$ \\
\hline
\end{tabular}

Applying this theoretical framework, we expect to gain a comprehensive insight into how SCAT has been legitimized in the institutional context of a fully developed schoolbased and company-based vocational training system.

\section{Methods}

We use a case study design, which is particularly suitable for investigating "a contemporary phenomenon (the 'case') in depth and within its real-world context, especially when the boundaries between phenomenon and context may not be clearly evident" (Yin 2018, p. 45). The case-study approach is well adapted for gaining a deeper insight into and understanding of the institutional development of SCAT. We expect to make boundaries and relationships, but also competition with other VET pathways evident. However, we do not aim to present a systematic comparison with other VET training institutions in 
the Austrian skill-formation system. Rather, we intend to examine the internal institutional logic of SCAT and to make institutional interfaces visible by applying the theoretical framework described above.

For the case study we draw on a wide range of data relevant for understanding SCAT. The integration of different sources of data may contribute to an increase in the reliability and validity of the case study (Shoaib and Mujtaba 2016; Yin 2018). The collection of various data was guided by the theoretical framework, but also by the field knowledge of the authors.

For analysis we use the following data: scientific articles, reports, completed evaluations (based on standardized surveys, interviews, analysis of mass data), legal texts, and statistical databases (e.g. provided by Statistics Austria). With the triangulation of this data we aim to draw a comprehensive picture of the institutional development of SCAT.

\section{Results and discussion}

\section{Institutional legacy and historical development of SCAT in the context of active labour} market policy

SCAT is legally anchored in the Vocational Training Act of 1998. A historical analysis of political processes shows that SCAT was not planned at the drawing board, but is rooted in a long tradition of training in workshops (Durazzi and Geyer 2019).

Its roots can be found, for example, in initiatives in the inter-war period (1930s) and the post-war period (from 1945), in which welfare measures were combined with training in workshops for young people. The Youth Employment Act of 1953 (Jugendeinstellungsgesetz 1953) reduced a high youth unemployment rate by obliging entrepreneurs to employ young people (Bamberg 2015). This was followed by a phase of economic upswing and almost full employment in the Austrian labour market that lasted until the 1980s, when another crisis in the apprenticeship market occurred (associated with high youth unemployment). A complex set of active labour-market policy measures was developed to combat this crisis in 1983. Programs, e.g. employability training for disadvantaged young people, were implemented at this time (Lassnigg 1998). In the 1980s, an additional program of intensive training for skilled workers was established for the unemployed, which made it possible to obtain vocational qualifications at supracompany training centres, mostly provided by institutions of adult education. We see direct continuity here with the implementation of SCAT, namely in pilot measures realized by adult education institutions and training workshops within the framework of the National Action Plan for Employment (1997-2001). This provided basic training within the framework of active labour-market policy with full credits offered for apprenticeship qualifications (BMASK 2012).

However, after a brief improvement, the gap between the number of training places and applications for those places increased again in the mid-1990s (Schneeberger 2009). As a response, the Youth Safety Net Act of 1997 (Jugendausbildungssicherungs-Gesetz 1997) established a social safety net for all young people who could not find an apprenticeship by providing non-company-based training opportunities (e.g. apprenticeship foundations) (Hofbauer et al. 2014). The idea was that the measures would be limited in terms of time and quantity, until the apprenticeship market recovered. This expectation was not fulfilled, but the gap in the apprenticeship market turned out to be a structural 
problem (Schneeberger 2009; Durazzi and Geyer 2019). Moreover, the number of training companies has been falling continuously from 40,000 (in 1999) to 28,000 (in 2018) (Dornmayr and Nowak 2019, p. 38). This is an indicator that company training behaviour has changed considerably over the last two decades.

Subsequently this has led to an expansion of supra-company training provision within the framework of a training guarantee (since 2007) (Atzmüller and Knecht 2017). SCAT was legally anchored in the Vocational Training Act of 2008 (Amendment of Vocational Training Act $1969 \$ \$ 30$ and 30b). With the legal adoption of a training obligation up to age 18, SCAT was further anchored in law by being explicitly mentioned as a legitimized form of training (in accordance with $\$ 1$ Para. 2 of the Training Obligation Act 2017), and thus became a structural component of the Austrian VET-system.

An analysis of its historical and legal implementation has two interesting aspects:

1. The institutional development of SCAT was not coincidental and was not planned from the drawing board, so to speak. Rather, it was based on previous institutional experience with similar measures and approaches to labour market policy (Durazzi and Geyer 2019).

2. The institutional development of SCAT has always been specifically linked to conditions on the labour- and apprenticeship market (Lassnigg 2017).

\section{Regulatory design: SCAT as an instrument of labour market policy}

The historical development of SCAT shows that it has become institutionalized step by step. Apprenticeship training was legally opened up outside companies by allowing supra-company training institutions to be recognized as equivalent learning venues if they have a suitable training infrastructure. At the same time, the Labour Market Service Act (Arbeitsmarktservicegesetz 1994) also enshrined SCAT as a "special labour market policy measure" (Amendment 2008 of the Labour Market Act $\mathbb{\$} 38 \mathrm{~d}$ ). This ensures that SCAT is financed by the public sector within the framework of labour market policy. SCAT is therefore potentially open to all apprenticeship occupations regulated by the Federal Minister of Economics (with nation-wide job profiles, currently around 200 different profiles). Similar to learners in a company-based apprenticeship, SCAT apprentices must attend vocational school part-time and can also take the final apprenticeship examination at the end of training. In addition, training in SCAT can only take place in one of the specific job profiles offered, although training-place offers (regarding which profession and in what number) are determined by regional advisory councils of the PES, upon which the social partners have considerable influence.

The central target group of SCAT is young people who have completed compulsory schooling but are not able to find an apprenticeship place due to a quantitative mismatch on the apprenticeship market. Therefore, young people are supported by the Public Employment Service (PES) (Labour Market Act $\$ 38$ d Para. 1). In addition, SCAT is particularly aimed at disadvantaged and vulnerable groups (those with a lack of parental support, learning disabilities, early school leavers). During training, learners receive a training compensation from the PES. 
At the regulatory level, there is a hybrid construction at the institutional interface of labour market policy and initial VET: SCAT is a labour market policy measure that is implemented within the legal framework of apprenticeship training. Since 2020, the institutional relationship to company-based apprenticeship training has also been clearly defined in law (amendment to the Vocational Training Act of March 2020): SCAT should complement and support apprenticeship training. One of SCAT's central tasks is placement in a company-based apprenticeship training scheme.

Governance structures at the highest level are also enshrined in law. Both the governance of apprenticeship training (which includes SCAT) and the governance of the implementation are carried out by tripartite actors: representatives of the relevant ministries (Ministry of Economic Affairs, Ministry of Social Affairs), the Chamber of Labour (employees' representatives), and the Chamber of Commerce (employers' representatives). The concrete implementation of SCAT on a regional level is carried out by the PES regional offices, which are largely controlled by the advisory board through the aforementioned tripartite group of actors. This means, in concrete terms: Actors at a regional level are responsible for the implementation and provision of training offers in the framework of SCAT. This also means that normative negotiation processes (provision of training, further institutional development, quality control, etc.) take place in legally defined structures. Supra-company training centres, where the training is carried out, are contracted by the regional PES after a tendering procedure.

In this respect, it can be summarized that the systemic location, legal regulation and the determining actors are clearly part of the labour market or social policy system. Pedagogical norms or professional positions of trainers are subordinate principles and are only effective in shaping the practical level. This confirms Lassnigg's assessment that the implementation of SCAT is not founded on professional learning, but was and is developed in response to crisis situations in the apprenticeship market. Data and findings on the dimensions identified by Durazzi and Geyer and their historical conditions in Austria are summarized below.

\section{The normative struggle for and against SCAT}

In some member states of the European Union, youth unemployment reached a threatening level during the financial and economic crisis that hit in 2008. In Austria, debate about the economic and social consequences of mass unemployment among people under the age of 25 began earlier. At the end of the 1990s the federal government, led by the social democrats, began to proactively combat unemployment among young people. In the tradition of Austrian labour market policy, the operationalization of concepts and measures was entrusted to the social partners. In the negotiation processes, two positions were initially opposed (Durazzi and Geyer 2019): The Austrian Trade Union Federation (ÖGB) and the Chamber of Labour (AK) represented the position that all young people should be given the opportunity to acquire a training qualification of equivalent value. This means that training opportunities should be made available for those to whom companies were not providing apprenticeship training. The Chamber of Commerce (WKÖ), on the other hand, argued that this would weaken the company-based apprenticeship system and would decouple the apprenticeship market from the employment system. State intervention would also lead to a decrease in company involvement 
in apprenticeship training. The employers identified a solution in the deregulation of the apprenticeship system, financial support for training companies, and the introduction of a part-time qualification (target group: young people who cannot fully meet the requirements for an apprenticeship; finally introduced in 2003) within the apprenticeship framework.

In the end, the opposing policy claims were implemented in a spirit of compromise: The measure proposed by the trade unions was implemented directly. However, a financial subsidy scheme for training companies was introduced at the same time to support the company-based apprenticeship system (Dornmayr et al. 2016).

Even in the following Conservative periods of government (2000-2007), the measures survived because the apprenticeship market crisis turned out to be structural. Ending the measures would have led to an abrupt increase in youth unemployment, which nevertheless reached a new high in 2004. This significantly increased pressure on the government, which in 2007 introduced a training guarantee. In 2007, the Social Democrats took over again, which led to a stronger legal anchoring of SCAT (Schneeberger 2009; Durazzi and Geyer 2019). During this time SCAT became a permanent structural element of the VET system. In 2017, there was another change to the Conservative government. Once again SCAT quickly came under pressure. In this context, SCAT's brokerage mandate in the company-based system was clarified (that is, amendment to become the Vocational Training Act, 2020). In normative terms, this means that SCAT is clearly subordinate to the company-based apprenticeship training system.

This brief outline clearly shows the lack of common objectives for SCAT on the part of various interest groups. But it also reflects a power struggle to control apprenticeship training. SCAT enables employee representatives to have greater control over training. This is achieved on the one hand through the local governance structures of the PES (employee representatives are key actors in the tripartite governance structure), but also through the implementation of SCAT (some large training providers are supported by the trade unions). This leads unsurprisingly to resistance on the side of employers, who traditionally see apprenticeship training as primarily a matter for companies (Durazzi and Geyer 2019) and thus SCAT as a supplementary measure for a partly non-functional apprenticeship market.

Linking SCAT to labour market policy measures may be seen as an attempt to balance conflicting interests. It ensures the social inclusion of disadvantaged young people in the apprenticeship market while at the same time achieving economic efficiency by matching economic needs and training provisions (Di Maio et al. 2019).

\section{Regional dispersal and organizational variation}

Empirically, a regional divergence can be observed in the implementation of SCAT. About 24\% of apprentices in Vienna are trained in SCAT, but only 1\% in Tyrol. However, the proportion of SCAT apprentices is in turn strongly linked to the empirically observed gap on the apprenticeship market (see Fig. 1).

From this we can derive that organizational variation in implementation is regionally diverse, and is closely coupled to the conditions of the regional apprenticeship markets. Thus, on a regional level, the institutionalization process of SCAT is clearly 


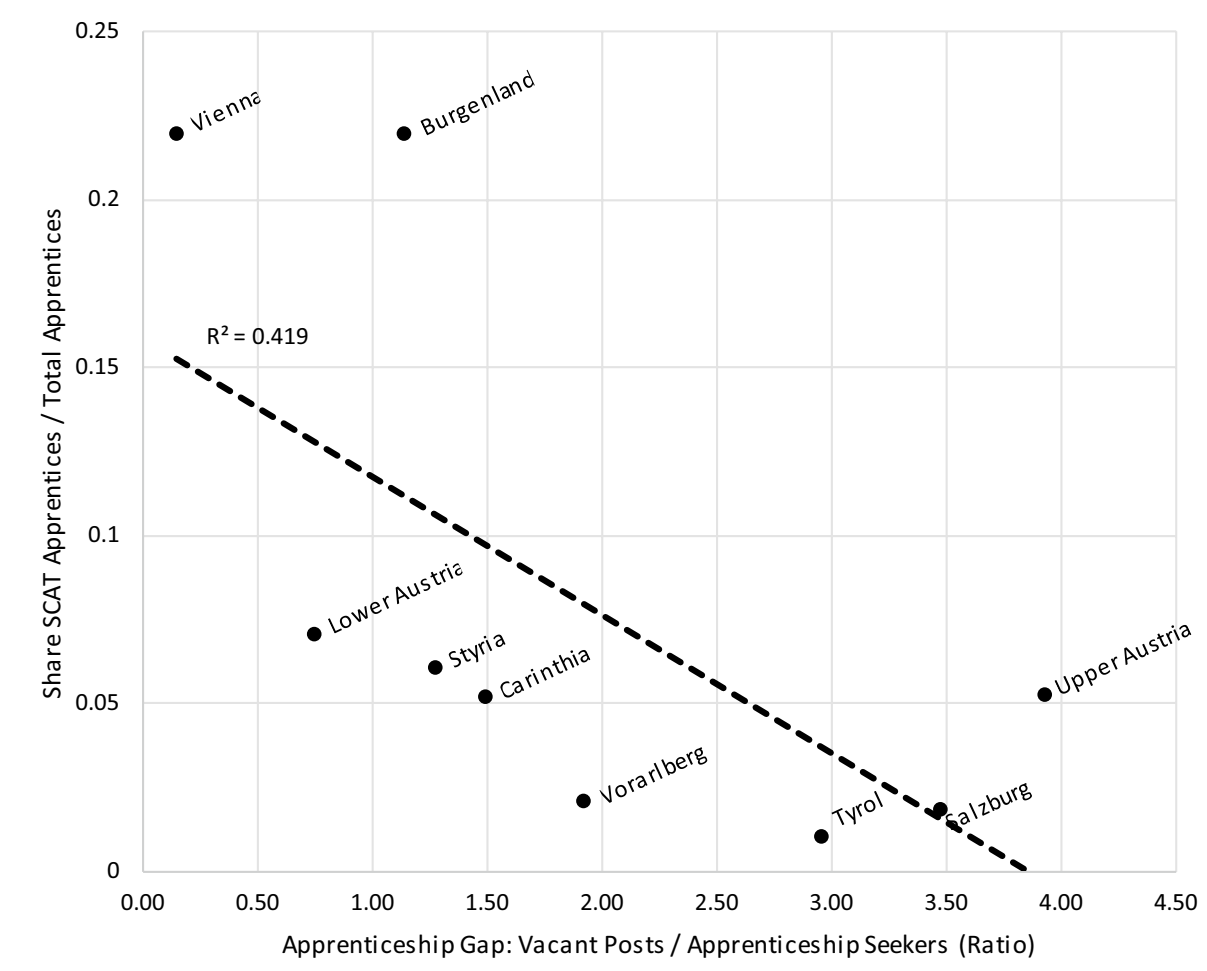

Fig. 1 Scatterplot apprenticeship gap (reference date: 30.09.2018) by share of SCAT apprentices (reference date: 31.12 .2018 ). (Data provided by Dornmayr and Nowak 2019, p. 46 and p. 155. Figure by the authors)

linked to dysfunctionalities on the training market. Functioning apprenticeship markets provide barely any foundation for the normative legitimation of SCAT.

The strong regionalization of SCAT's governance structure, which is analogous to the decentralised implementation of Austrian labour market policy, results in specific regional models reacting to regional conditions. A rudimentary conceptual analysis of regional implementation models shows different standards within the general SCAT framework, e.g. with regard to the arrangement of placements in internships, dropout prevention, design of initial phases, indicators for performance monitoring, and support measures for young women (Steiner et al. 2019, pp. 94-124). However, the reasons for this institutional variance have not yet been examined in detail.

This finding is an indicator that the institutionalization process of SCAT is closely linked to conditions on the apprenticeship market. This raises the question of which institutional mechanisms are used for coordination between SCAT and the apprenticeship and labour markets in a multilayered governance system. For example, whether non-market-related considerations play a role in addition to the legitimate "market-correcting" logic of dysfunctional apprenticeship markets and how regional actors address these issues differently. This tension also reflects the two goals of inclusion and economic efficiency (Di Maio et al. 2019). But again, this highly relevant question has not yet been adequately addressed in research. 


\section{Costs and benefits of SCAT: a matter of perspective}

An essential part of the struggle for normative legitimacy relates to the normative assessment of the financial costs and benefits of SCAT. The different evaluations of costs and benefits reflect the different normative positions of the actors. Employers' representatives point out that the total public expenditure for SCAT (costs for vocational school, costs for labour-market services, additional state funds) of around 19,000 euros per training place is about three times higher than the cost of company-based apprenticeship training (costs for vocational school, public subsidies) of around 6500 euros (Dornmayr and Nowak 2019, p. 111). This leads to the normative assessment that apprenticeship training should be promoted over SCAT. From this perspective, companies would bear the lion's share of training costs. However, this education perspective appears limited when we consider the benefits for employers from training apprenticeships (equivalent to the productive performance of apprentices and the reduction of recruitment costs for skilled workers) (Schlögl and Mayerl 2016; Schönfeld et al. 2010; Strupler et al. 2012).

Contrasting the individual cost-and-benefit considerations of training are social-investive legitimation figures, based on fiscal and economic considerations. Social-investive legitimation figures are primarily related to increasing competitiveness and economic growth. This also includes measures that aim to improve human capital (Atzmüller and Knecht 2016). From the point of view of social investment argumentation, measures for the inclusion of young people are at the same time economically efficient.

Specifically, this view argues that fiscal and economic-opportunity costs result from the apprenticeship gap in the form of lower tax and levy payments due to lower labour market integration and lower qualification levels.

In this context, calculations based on various scenarios (carried out by employee representatives) show positive fiscal policy effects resulting from investment in SCAT. Accordingly, already after five (the optimistic scenario) to seven years (the pessimistic scenario) direct and indirect employment effects (taxes and levies) should exceed investments in SCAT (Hofbauer et al. 2014). The additional costs of unemployment and the resulting psychosocial problems and social exclusion were not quantified here, however.

Current calculations (commissioned by the Professional Association of Private Educational Institutions), based on employment and income trends between 2008 and 2017, show a similar picture. The net expenditure burden in the year of SCAT financing (2008/2009) amounted to about 33 million euros (which resulted in about 39 million euros with an appreciation of $2 \%$ p.a.). This was offset by additional revenues (taxes and levies) of around 42 million euros due to a higher productivity of SCAT graduates in the period from 2014 to 2017 (Holl et al. 2018). According to these model calculations, a return of investment through SCAT can already be expected in the medium term (Fig. 2).

The results of the above-presented calculations can be cited as a further normative legitimation of the social-investive explanatory figure for SCAT. Despite its high costs, SCAT is a training option that generates high added-value in the medium term. Taking into account the fact that the calculation of causal returns to education is ultimately difficult to estimate, this approach attempts to legitimizes the perspective that the inclusion of young people is rational for economic reasons. This also makes it possible to 
avert further attempts to counteract the institutionalization process of SCAT, but to also promote clear subordination to the regular apprenticeship system.

\section{The symbolic value of the SCAT certificate on the labour market}

Table 1 shows the results of graduate/dropout transition from VET and employment into apprenticeship/SCAT by indicating status 36 months after training completion or dropout. The figures show that apprenticeship training after graduation achieves a very high share of labour market integration. In comparison, SCAT achieves a considerably lower degree of labour market integration. The question of whether this can be considered a success is again a normative one. But it tends to indicate a positive evaluation of SCAT outcomes when contrasted with transitional patterns of dropout in company-based apprenticeships, including opportunity scenarios (young people with no certificate of completion, higher rates of unemployment, lower income, and other social situations).

The respectable acceptance of SCAT graduates in the labour market shows that the normative expectations and social-investment considerations associated with this model are largely met. The symbolic value objectified in the labour-market success of SCAT participants is a further source of legitimacy that secures the status of SCAT within the vocational training system.

\section{Participation of training companies}

There is discussion about why companies decide to train apprentices as part of apprenticeship programmes and why this works better in some countries than in others. Against the background of human capital theory (Becker 2009), the question arises as to why companies incur the costs of training if there is a risk that other companies will poach apprentices after they have completed training (Harhoff and Kane 1997). The answer found in Skill Formation literature (Busemeyer and Trampusch 2012) is that historically, specific institutional configurations have emerged that ensure that training activity becomes "rational" for enterprises (e.g. collective control, compressed wage structures).

Cost-benefit surveys in various countries show that training not only has costs but also benefits. Apprentices are productive during their training and reduce recruitment costs by meeting the company's need for skilled workers (Schlögl and Mayerl

Table 1 Labour market status 36 months after training. Source: * Dornmayr et al. 2016, p. 72. Graduation years 2008-2013

\begin{tabular}{|c|c|c|c|c|}
\hline & \multicolumn{2}{|l|}{ Graduates } & \multicolumn{2}{|l|}{ Dropouts } \\
\hline & $\begin{array}{l}\text { Company-based } \\
\text { apprenticeship (\%) }\end{array}$ & SCAT (\%) & $\begin{array}{l}\text { Company-based } \\
\text { apprenticeship (\%) }\end{array}$ & SCAT (\%) \\
\hline In Training & 3 & 8 & 13 & 31 \\
\hline Employment & 81 & 58 & 39 & 29 \\
\hline Unemployed (PES) & 7 & 22 & 19 & 26 \\
\hline Other & 9 & 13 & 29 & 14 \\
\hline
\end{tabular}


Public expenditure of 58.13 million euros in 2008/09 for the financing of SCAT.

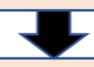

Recoveries from taxes and levies of 24.99 million euros.

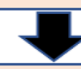

Actual expenditure burden in 2008/09 EUR 33.13 results in an "investment" of 39.21 million euros with an appreciation of $2 \%$ p.a. from 2017 perspective.

In the course of the fourth year, a fiscal surplus will emerge.

This results in (from perspective 2017) additional income up to and including 2017 of 41.79 million euros.

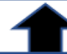

This results in additional public revenues of 40.73 million euros at current prices.

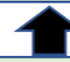

The additional SCAT-related added value in the years 2014-2017 due to the higher productivity of the SCAT participants.

Fig. 2 Fiscal analysis of SCAT (Source: Holl et al. (2018, p. 18), representation recreated and translated by the authors)

2016; Schönfeld et al. 2010; Strupler et al. 2012). In this context, the question arises as to whether and how SCAT contributes to a change in in-company training behaviour. A first approximation of this question is provided by company surveys within the context of (regional) evaluations of SCAT (Bergmann et al. 2011; Friedl-Schafferhans and Hausegger 2013; Löffler and Helling 2011). As a rule, these are companies that provide internships within the framework of cooperation with supra-company training institutions.

The findings of the above-mentioned evaluations show a consistent picture. Although there are social motives for the provision of internships within the framework of SCAT, there are nevertheless primary rational reasons for companies to participate. Cooperation with SCAT training institutions is mainly used to recruit and screen SCAT apprentices for regular placement in a company-based apprenticeship training. It is attractive for the companies that almost no costs are incurred during the placement period, as the remuneration of the trainees is paid by the PES. It is also noteworthy that the individual prerequisites of SCAT apprentices are assessed as almost equivalent to those of regular apprentices (especially in terms of social skills). Cooperation with SCAT thus becomes an attractive recruitment channel for 
companies, especially since complementary educational resources (socio-pedagogical support in SCAT centres is a central pillar of the model) can also be used.

From an institutional perspective, this might have been a nucleus for changing incompany training attitudes. The recruitment of apprentices by the SCAT has advantages both in terms of costs and the screening of young people. In addition, the (compensatory) training for those who lack basic skills (e.g. social skills, language skills) can be outsourced to SCAT without incurring additional costs. Although such considerations are not (yet) in the foreground among companies (Bergmann et al. 2011, p. 110), the institutional conditions for this are given and may be further initialized by considerations such as strengthening the placement aspect.

\section{Acceptance of SCAT by learners}

These evaluations show that the SCAT training model is also well accepted by the target group (Friedl-Schafferhans and Hausegger 2013; Löffler and Helling 2011). Nevertheless, the collected perceptions of those who drop out of the system reveal the main problems with this training model. From the young people's point of view, the matching problem is a central issue. The dropout risk is higher if the occupation trained in SCAT does not correspond with the desired occupation.

This aspect again highlights the governance problem of balancing social inclusion and economic efficiency. The inclusive goal of offering vocational qualification to all, including disadvantaged young people, is not always compatible with the labour-market-oriented provision of training places if the preferences of young people do not match them. Institutionally, this problem could be solved by introducing phases of vocational orientation prior to SCAT itself, which are intended to resolve these tensions. De facto, however, this means that these orientation measures are used to "convince" young people of the structure of the occupation profile spectrum offered (only occupational profiles within the framework demanded by the labour market are offered).

\section{Conclusions and outlook}

We have analysed the Supra-Company Apprenticeship Training (SCAT) in Austria based on the framework of neo-institutionalism, which proposes three key dimensions for analysing apprenticeship systems: the regulatory, normative, and cultural-cognitive dimensions (Powell and DiMaggio 1991; Lowndes and Roberts 2013; Scott 2014). The regulatory dimension refers to the institutional legacy and historical development of SCAT in the context of active labour market policy and regulatory design as an instrument of labour market policy. Our analysis shows that, despite a traditionally well-developed social partnership in Austria, the reconciliation of interests does not go so far as to develop a sustainable consensus model. Rather, broad programs have been rolled out under the political leadership of the Social Democrats, building on previous models with strong social-democratic and trade-union influence, in times of crisis in youth unemployment. However, it was only when it became evident that company-based training would not be able to offer training places to all young people in the long term that the legal basis for SCAT was established. 
The normative dimension refers to the struggle for and against SCAT, its regional dispersal and institutional variation, and diverse interpretations of the costs and benefits of SCAT. Our analysis shows, through a comparative analyses of cost-benefit models adopted from other German-speaking countries, that the actual training costs for companies and the public do not constitute misallocations. On the contrary, model calculations have shown that cost-benefit perspectives would be in favour of public expenditure, particularly for young people such as those who constitute SCAT's target group (Additional file 1).

The cultural-cognitive dimension refers to the symbolic value of SCAT certificates on the labour market, the participation of training companies, and acceptance of SCAT by learners. Our analysis shows that although a company-based training place is preferred by learners to training in SCAT, it is clear that SCAT graduates perform better in terms of key labour market indicators than people who have not completed vocational training or who have dropped out.

In summary, there seem to be numerous factors that suggest a sustainable anchoring of SCAT in the Austrian training model of skill formation. The future will show whether this will bear out in phases of training-place overhang. The scheme will probably only succeed if a path-dependent framework (North 1990) which combines the coordination of action through complementarity and at the same time the complementarity through the internal legitimation of subsystems of this triple structure.

Against the background of a vocational education and training system that is entirely publicly financed and controlled, and a company-based training model that sees itself as rational investment in the recruitment of skilled workers on the part of individual companies, certain questions remain unanswered:

1. What counts as legitimation for a model of qualification acquisition controlled by labour-market parties? In particular, this will depend on whether trade unions and the Ministry of Social Affairs, which each claim this field of vocational education and training policy for themselves, can continue to exert their influence. In addition to the Ministry of Education and employers' associations, this is a third actor who proclaims systemic relevance via the Public Employment Service, calling for training options not to be dependent on economic factors, but to be anchored in social inclusion through initial VET in a sustainable manner.

2. Apparent questions of detail, such as how these training courses should and will be conducted and in which occupational profiles, are thus given considerably more weight. It will have to be clarified whether the training places offered by SCAT can be reduced to a single instrument for combating quantitative mismatch, or whether corrective influences can also be exerted on the training provision offered by companies.

Although it cannot be ruled out that, despite several indications of stabilization, under certain political conditions and a phase of oversupply of apprenticeships this scheme will collapse, it seems more plausible, even with regard to Austria's long history of apprenticeship training, that it will remain active in one form or another. However, it does not have to remain a third pillar of VET. The fragile autonomy of the development of SCAT in Austria as a transition instrument motivated by labour 
market policy, which has been manifested for decades, could however, depending on the political will, come close to one of the current models in the other two Germanspeaking countries with a high proportion of apprentices in vocational training. Compared to Switzerland, this would be the emancipation of inter-company qualification as a third pillar with its own educational mandate. Or, following the German model, towards a compensatory, possibly upstream qualification level for access to in-company training positions. Accordingly, two scenarios are conceivable:

1. Either the workshops could become a third place of learning, in a then tripartite system, as an inter-company form of vocational learning, as the inter-company courses in the Swiss model, for example, embody. Maybe even integration as a practical learning site for full-time, school-based training (that is, subject-specific practical instruction) also seems conceivable.

2. Does SCAT aim (as the goal is still placement in in-company training) to some extent to compensate for the personal deficits of young people on the one hand, or for training deficits or restrictions on the part of the training providing companies on the other? This would mean that the formal and informal contexts of justification are not congruent, but that current SCAT practice is nevertheless acceptable to different actors and/or more presentable than alternatives. Thus, such an offer would have the role of cushioning the weaknesses of a system in a way that is not publicly negotiated; perhaps because the system itself is classified as worth preserving by all actors involved.

The future will show whether the SCAT model will remain robust even in phases of relaxation on the apprenticeship market, whether it will become a niche offering or disappear altogether and be revived in times of crisis.

\section{Supplementary information}

Supplementary information accompanies this paper at https://doi.org/10.1186/s40461-020-00102-y.

Additional file 1. Scat graph plus Data.

\section{Abbreviations}

AK: Chamber of Labour; BAG: Vocational Training Act; ÖGB: Trade Union Federation; IVET: Initial Vocational Education and Training; PES: Public Employment Service; SCAT: Supra-company Apprenticeship Training; VET: Vocational Education and Training; WKÖ: Economic Chamber.

Acknowledgements

Not applicable.

\section{Authors' contributions}

The manuscript's concept was developed for the "2nd BIBB Conference on the Economics of Vocational Education and Training: Markets-Institutions - Systems" by PS and MM. The other authors assisted in the preparation of the final version of the paper. All authors read and approved the final manuscript.

\section{Funding}

No external funding was obtained for the project. The resources for writing the manuscript were provided by University Klagenfurt and Austrian Institute for Research on Vocational Training.

\section{Availability of data and materials}

All data generated or analysed during this study are included in this published article. The paper refers to ongoing research in the team of authors and includes data form several projects and data from national statistical services. The datasets used and/or analysed during the current study are available due to privacy or other restrictions from the corresponding author on reasonable request. All of these cannot be provided in English at present. 
Ethics approval and consent to participate

Given the secondary nature of the data, no direct contact with the original participants was made.

\section{Consent for publication}

All authors approved the manuscript for submission. This manuscript has not been published or submitted for publication elsewhere.

Competing interests

The authors declare no competing interests.

\section{Author details}

${ }^{1}$ Department of Educational Science, University Klagenfurt, Universitätsstraße 65-67, 9020 Klagenfurt am Wörthersee, Austria. ${ }^{2}$ Austrian Institute for Research On Vocational Training, Margaretenstraße 166/2, 1050 Vienna, Austria.

Received: 12 December 2019 Accepted: 6 November 2020

Published online: 19 November 2020

\section{References}

Atzmüller R, Knecht A (2016) Neoliberale Transformation der österreichischen Beschäftigungspolitik für Jugendliche. SWS-Rundschau 56:112-132

Atzmüller R, Knecht A (2017) Vocational training in the framework of the 'Austrian Training Guarantee.'In: Otto H-U, Egdell $\checkmark$, Bonvin J-M, Atzmüller R (eds) Empowering Young People in Disempowering Times. Northampton, Cheltenham, pp 115-128

BMASK (2012) Dokumentation Aktive Arbeitsmarktpolitik in Österreich. 1994 - 2011. BMASK, Wien

Bamberg W (2015) Jugend am Werk 1945-2015 - 70 Jahre Festschrift. Jugend am Werk, Wien

Becker GS (2009) Human Capital: A Theoretical and Empirical Analysis, with Special Reference to Education. University of Chicago Press, Chicago

Bergmann N, Lechner F, Matt I et al (2011) Evaluierung der überbetrieblichen Lehrausbildung (ÜBA) in Österreich. L\&R, Wien

Bonoli G, Wilson A (2019) Bringing firms on board. Inclusiveness of the dual apprenticeship systems in Germany, Switzerland and Denmark. International Journal of Social Welfare 28:369-379. https://doi.org/10.1111/ijsw.12371

Bourdieu P (1987) Die feinen Unterschiede. Suhrkamp, Frankfurt a. Main, Kritik der gesellschaftlichen Urteilskraft Busemeyer MR, Trampusch C (eds) (2012) The political economy of collective skill formation. Oxford University Press, Oxford, New York

DiMaggio PJ, Powell WW (1983) The iron cage revisited: institutional isomorphism and collective rationality in organizational fields. Am Sociol Rev 48:147-160. https://doi.org/10.2307/2095101

Dornmayr H, Nowak S (2019) Lehrlingsausbildung im Überblick 2019. ibw, Wien.

Dornmayr H, Petanovitsch A, Winkler B (2016) Kontext- und Implementationsanalyse der betrieblichen Lehrstellenförderung (gemäß 19c BAG). Teilbericht im Rahmen der ibw-öibf-Studie"Hintergrundanalyse zur Wirksamkeit der betrieblichen Lehrstellenförderung (gemäß 19c BAG)". ibw, öibf, Wien.

Durazzi N, Geyer L (2019) Social inclusion in the knowledge economy: unions' strategies and institutional change in the Austrian and German training systems. Socio-Econ Rev 18(1):103-124. https://doi.org/10.1093/soceco/mwz010

Emmenegger P, Graf L, Trampusch C (2019) The governance of decentralised cooperation in collective training systems: a review and conceptualisation. J Vocat Educ Train 71(1):21-45. https://doi.org/10.1080/13636820.2018.1498906

Friedl-Schafferhans M, Hausegger T (2013) Begleitende Evaluierung der Überbetrieblichen Berufsausbildung 2 in Wien. prospect, Wien

Goos M, Manning A, Salomons A (2009) Job Polarization in Europe. Am Econ Rev 99(2):58-63. https://doi.org/10.1257/ aer.99.2.58

Graf L, Lassnigg L, Powell JJW (2012) Austrian Corporatism and Institutional Change in the Relationship between Apprenticeship Training and School-Based VET. In: Busemeyer MR, Trampusch C (eds) The political economy of collective skill formation. Oxford University Press, Oxford, New York, pp 150-178

Harhoff D, Kane TJ (1997) Is the German apprenticeship system a panacea for the US labor market? J Popul Econ 10(2):171-196. https://doi.org/10.1007/s001480050037

Hofbauer S, Kugi-Mazza E, Sinowatz L (2014) Erfolgsmodell überbetriebliche Ausbildung: Eine Analyse der Auswirkung auf betroffene Jugendliche und öffentliche Haushalte in Österreich. WISO - Wirtschafts- und sozialpolitische Zeitschrift des Instituts für Sozial- und Wirtschaftswissenschaften 37(3):51-66

Holl J, Kernbeiß G, Wagner-Pinter M (2018) Die überbetriebliche Lehrausbildung. Eine Analyse in mittelfristiger Perspektive, Synthesis, Wien

Lassnigg L (1998) Youth Labour Market Policy in Austria 1980-1997. IHS, Wien

Lassnigg L (2017) Apprenticeship policies coping with the crisis: A comparison of Austria with Germany and Switzerland. In: Pilz M (ed) Vocational Education and Training in Times of Economic Crisis. Springer, Cham, pp 127-148

Löffler R, Helling K (2011) Überbetriebliche Lehrausbildung in Tirol. ÖlBF, Wien

Lowndes V, Roberts M (2013) Why institutions matter: the new institutionalism in political science. Palgrave Macmillan, Basingstoke

Di Maio G, Graf L, Wilson A (2019) Torn between economic efficiency and social equality? Short-track apprenticeships in Denmark, Germany and Switzerland. Eur Educ Res J 18(6):1-25. https://doi.org/10.1177/1474904119869561

Di Maio G, Graf L, Wilson A (2020) Embedded flexibilization and polite employer domination: the case of short-track apprenticeships in Switzerland. Empirical Research in Vocational Education and Training 12(1):1-21. https://doi. org/10.1186/s40461-020-00088-7 
North D (1990) Institutions, institutional change and economic performance. Cambridge University Press, Cambridge Powell WW, DiMaggio P (eds) (1991) The New institutionalism in organizational analysis. University of Chicago Press, Chicago

Protsch P, Solga H (2016) The social stratification of the German VET system. J Educ Work 29(6):637-661. https://doi. org/10.1080/13639080.2015.1024643

Schlögl P (2017) Industrie-, Arbeits- und Produktionsschulen. Von Denkmotiven umfassender Schulreform zur Benachteiligtenförderung der Gegenwart. In: Niedermair G (ed) Schriftenreihe für Berufs- und Betriebspädagogik: Vol. 10. Berufliche Benachteiligtenförderung. Trauner, Linz, pp 113-134

Schlögl P, Mayerl M (2016) Betriebsbefragung zu Kosten und Nutzen der Lehrausbildung in Österreich. Teilbericht im Rahmen der ibw-öibf-Studie'Hintergrundanalyse zur Wirksamkeit der betrieblichen Lehrstellenförderung (gemäß 19c BAG)'. ÖIBF, Wien

Schlögl P, Stock M, Mayerl M (2019) Berufliche Erstausbildung: Herausforderungen und Entwicklungs aufgaben in einem bedeutsamen Bildungssegment Österreichs. In: Breit S, Eder F, Krainer K, Schreiner C, Seel A, Spiel C (eds) Nationaler Bildungsbericht Österreich 2018, Band 2. Fokussierte Analysen und Zukunftsperspektiven für das Bildungswesen. https://doi.org/10.17888/nbb2018-2-7

Schneeberger A (2009) Bildungsgarantie bis zum 18./19. Lebensjahr. Entwicklungen und Perspektiven in der Berufsbildung. In: Specht W (ed) Nationaler Bildungsbericht Österreich 2009. Graz, Leykam, pp 55-72

Schönfeld G, Wenzelmann F, Dionisus R et al (2010) Kosten und Nutzen der dualen Ausbildung aus Sicht der Betriebe. Ergebnisse der vierten BIBB-Kosten-Nutzen-Erhebung, Bertelsmann, Bonn

Scott WR (2014) Institutions and organizations: ideas, interests, and identities, 4th edn. Sage, Los Angeles

Shoaib S, Mujtaba BG (2016) Use it or lose it: Prudently using case study as a research and educational strategy. Am J Educ Learn 1(2):83-93. https://doi.org/10.20448/804.1.2.83.93

Steiner M, PessI G, Leitner A et al (2019) Ausbildung bis 18. IHS, öibf, Wien, Wissenschaftliche Begleitung der Implementierung und Umsetzung des Ausbildungspflichtgesetzes

Strupler M, Wolter SC, Moser M (2012) Die duale Lehre: eine Erfolgsgeschichte - auch für die Betriebe: Ergebnisse der dritten Kosten-Nutzen-Erhebung der Lehrlingsausbildung aus der Sicht der Betriebe. Rüegger, Zürich

Yin RK (2018) Case study research and applications: design and methods, 6th edn. Sage, Los Angeles

\section{Publisher's Note}

Springer Nature remains neutral with regard to jurisdictional claims in published maps and institutional affiliations.

\section{Submit your manuscript to a SpringerOpen ${ }^{\odot}$ journal and benefit from:}

- Convenient online submission

- Rigorous peer review

- Open access: articles freely available online

- High visibility within the field

Retaining the copyright to your article

Submit your next manuscript at $\gg$ springeropen.com 